\title{
Peningkatan Keterampilan Proses Sains Melalui Model Inkuiri Terbimbing bagi Siswa SD Negeri 1 Pingit Kabupaten Temanggung Jawa Tengah
}

\author{
Dinda Nasiroh \\ Pendidikan Profesi Guru, Pendidikan Guru Sekolah Dasar, Universitas Negeri Yogyakarta \\ Corresponding Author. Email: dindanasiroh@gmail.com
}

\begin{abstract}
This study aims to improve science process skills through a guided inquiry model for Grade IV students at SD Negeri 1 Pingit. This research method is classroom action research which consists of two cycles with 3 meetings. The research design follows the research phase which refers to the modification of the Kemmis and Mc. Taggart, namely 1) action planning, 2) action implementation, 3) observation, and 4) reflection. The data collection technique used is the observation of teacher activity, student activity and observation of science process skills. The data analysis technique of this research used descriptive analysis. The results of this study indicate that there is an increase in science process skills from cycle I and cycle II. The increase was proven from the analysis of science process skills in the first cycle with an average of 73.21 with a completeness of $78.95 \%$. In cycle II, science process skills obtained an average of 82.47 with $100 \%$ completeness. This shows that the guided inquiry model can improve the science process skills of fourth graders at SD Negeri 1 Pingit for the 2020/2021 academic year.
\end{abstract}

\begin{abstract}
Abstrak: Penelitian ini bertujuan untuk meningkatkan keterampilan proses sains melalui model inkuiri terbimbing bagi siswa Kelas IV di SD Negeri 1 Pingit. Metode penelitian ini adalah penelitian tindakan kelas yang terdiri atas dua siklus dengan 3 kali pertemuan. Rancangan penelitian mengikuti tahap penelitian yang mengacu pada modifikasi diagram Kemmis dan Mc. Taggart, yaitu 1) perencanaan tindakan, 2) pelaksanaan tindakan, 3) observasi, dan 4) refleksi. Teknik pengumpulan data yang digunakan adalah observasi aktivitas guru, aktivitas siswa dan observasi keterampilan proses sains. Teknik analisis data penelitian ini menggunakan analisis deskriptif. Hasil penelitian ini menunjukkan bahwa terjadi peningkatan keterampilan proses sains dari siklus I dan siklus II. Peningkatan tersebut dibuktikan daril analisis keterampilan proses sains pada siklus I dengan rata-rata 73,21 dengan ketuntasan 78,95\%. Pada siklus II keterampilan proses sains memperoleh rata-rata 82,47 dengan ketuntasan $100 \%$. Hal ini menunjukkan bahwa melalui model inkuiri terbimbing dapat meningkatkan keterampilan proses sains siswa kelas IV SD Negeri 1 Pingit tahun pelajaran 2020/2021.
\end{abstract}

\section{Article History}

Received: 24-05-2021

Revised: 13-06-2021

Accepted: 24-06-2021

Published: 07-07-2021

\section{Key Words:}

Science Process Skills, Guided Inquiry.

\section{Sejarah Artikel \\ Diterima: 24-05-2021 \\ Direvisi: 13-06-2021 \\ Disetujui: 24-06-2021 \\ Diterbitkan: 07-07-2021}

\author{
Kata Kunci: \\ Keterampilan Proses \\ Sains, Inkuiri \\ Terbimbing.
}

How to Cite: Nasiroh, D. (2021). Peningkatan Keterampilan Proses Sains Melalui Model Inkuiri Terbimbing bagi Siswa SD Negeri 1 Pingit Kabupaten Temanggung Jawa Tengah. Jurnal Paedagogy, 8(3), 447-453. doi:https://doi.org/10.33394/jp.v8i3.3904

https://doi.org/10.33394/jp.v8i3.3904

This is an open-access article under the CC-BY-SA License.

\section{Pendahuluan}

Kurikulum 2013 terdiri dari muatan-muatan pelajaran yang secara terintegrasi harus dipelajari oleh siswa salah satunya muatan IPA. Berdasarkan Peraturan Pemerintah No 22 Tahun 2006 tentang Standar Kompetensi Lulusan bahwa salah satu tujuan pembelajaran IPA di SD/MI adalah mengembangkan keterampilan proses untuk menyelidiki alam sekitar, memecahkan masalah dan membuat keputusan. Ilmu Pengetahuan Alam adalah ilmu yang mempelajari peristiwa-peristiwa atau gejala-gejala yang terjadi di alam ini. Pendapat ini selaras dengan Samatowa (2011) bahwa IPA membahas tentang gejala-gejala alam yang 
disusun secara sistematis yang didasarkan pada hasil percobaan dan pengamatan yang dilakukan oleh manusia. Belajar melalui pengalaman langsung membuat siswa tidak sekedar mengamati secara langsung tetapi siswa harus menghayati, terlibat langsung dalam perbuatan, dan bertanggung jawab terhadap hasilnya (Dimyati \& Mudjiono, 2009). Ango dalam Ardhiantari (2015) menyatakan bahwa pengalaman belajar siswa harus melatihkan keterampilan proses, seperti mengamati, mengklasifikasi dan memprediksi, menginferensi, dan berkomunikasi. Keterampilan ini sangat penting untuk membangun pemahaman konsep ilmiah siswa yang bermanfaat dan bermakna. Namun dikarenakan kondisi pandemi seperti ini, keterampilan proses sains kurang optimal sehingga penguasaan materi menjadi menurun. Seorang guru perlu menerapkan sebuah pendekatan yang mengarahkan siswa untuk berperan secara aktif dan menggali potensi yang ada pada dirinya sendiri, sehingga siswa mampu mengembangkan keterampilan proses sains seperti mengobservasi, mengklasifikasi, memprediksi, mengukur, menyimpulkan, dan mengkomunikasikan (Juhji, 2016).

Salah satu model pembelajaran yang melibatkan keaktifan siswa untuk mengkonstruk sendiri pengetahuannya adalah model inkuiri terbimbing (guided inquiry). Menurut Anam (2015) bahwa dalam proses pembelajaran inkuiri siswa tidak hanya berperan sebagai penerima pelajaran melalui penjelasan guru secara verbal, tetapi mereka berperan untuk menemukan sendiri inti dari materi pelajaran yang disampaikan. Dengan demikian siswa tidak hanya dituntut untuk menguasai materi pelajaran, tetapi lebih pada bagaimana mereka dapat menggunakan potensi yang dimilikinya untuk lebih mengembangkan pemahamannya terhadap materi. Peran guru dalam proses pembelajaran dengan inkuiri terbimbing menurut adalah menetukan topik penelitian yang akan dilakukan, mengembangkan pertanyaanpertanyaan terkait dengan topik yang akan diselidiki, menentukan prosedur atau langkahlangkah yang harus dilakukan oleh siswa, membimbing siswa dalam menganalisis data, menyediakan worksheet yang telah berbentuk kolom-kolom sehingga siswa cukup melengkapi dan membantu membuat kesimpulan (Wisudawati \& Sulistyowati, 2015; Seprianingsih, 2017; Ramadhanti, 2021).

Berdasarkan uraian di atas, model inkuiri terbimbing merupakan solusi paling tepat untuk mengatasi permasalahan keterampilan proses sains siswa yang masih kurang. Ada dua pendapat yang mengartikan pembelajaran inkuiri dan discovery. Pendapat pertama dari Renner \& Ragan (1968) menyatakan bahwa inkuiri dan discovery merupakan istilah sinonim yang biasa digunakan. Sedangkan menurut pendapat dari Trowbridge (1990) menyatakan bahwa discovery merupakan pengalaman untuk mengembangkan keterampilan proses dasar seperti mengamati, mengklasifikasikan, mengukur, memprediksi dan lain-lain. Sedangkan inkuiri mengembangkan proses discovery atau keterampilan proses dasar dengan lebih banyak lagi dan lebih tinggi tingkatanya seperti merumuskan masalah, merancang eksperimen, menganalisis data dll. Inkuiri juga dapat diartikan sebagai proses bertanya dan mencari tahu jawaban terhadap pertanyaan ilmiah yang diajukan guru kepada siswa. Mark Windschitl dalam (Avraamidou, 2016) berpendapat bahwa inkuiri ilmiah dapat mengambil berbagai bentuk di ruang kelas dan mendiskusikan gagasan oleh tingkat kemandirian yang dimiliki siswa dalam mengajukan dan menjawab pertanyaan.

Terdapat lima langkah inkuiri yaitu merumuskan masalah, mengajukan hipotesis, mengumpulkan data, menguji data dan membuat kesimpulan (Ambarsari, 2013). Sejalan dengan Hamruni (2012) secara umum proses pembelajaran menggunakan SPI (strategi pempelajaran inkuiri) mengikuti langkah-langkah orientasi, merumuskan masalah, mengajukan hipotesis, mengumpulkan data, menguji hipotesis dan merumuskan kesimpulan. 
Adapun penelitian ini bertujuan untuk meningkatkan keterampilan proses sains melalui model inkuiri terbimbing bagi siswa Kelas IV di SD Negeri 1 Pingit Kabupaten Temanggung Provinsi Jawa Tengah.

\section{Metode Penelitian}

Metode penelitian ini adalah penelitian tindakan kelas (PTK) yang mengacu pada modifikasi diagram yang dikemukakan oleh Kemmis dan Mc. Taggart. Tiap siklus dilakukan beberapa tahap, yaitu: 1) perencanaan tindakan, 2) pelaksanaan tindakan, 3) observasi, dan 4) refleksi. Penelitian ini dilaksanakan selama 2 siklus dan masing-masing siklus dilakukan sebanyak 3 kali pertemuan, yaitu siklus I terdiri dari pertemuan 1, 2 dan 3 . Siklus II juga terdiri dari 3 kali pertemuan dengan alokasi waktu setiap pertemuan adalah 2x 35 menit.

Penelitian ini telah dilaksanakan di SD Negeri 1 Pingit pada bulan Maret 2021. Subyek penelitian ini adalah siswa kelas IV tahun pelajaran 2020/2021, yang berjumlah 19 anak. Terdiri dari 11 siswa laki-laki dan 8 siswa perempuan. Observasi ini dilakukan pada saat penelitian atau dalam proses pembelajaran menggunakan model inkuiri terbimbing. Kegiatan observasi dibantu oleh seorang pengamat atau observer untuk mengamati semua aktivitas guru, aktivitas siswa dan keterampilan proses sains siswa dalam proses pembelajaran. Hasil observasi dicatat dalam lembar observasi aktivitas guru, aktivitas siswa dan keterampilan proses sains siswa yang telah disediakan serta mendokumentasikan semua kegiatan sebagai bukti telah dilaksanakannya penelitian tindakan kelas. Hasil pengamatan ini berupa data observasi untuk direfleksi sehingga pengamat dapat menceritakan keadaan sesungguhnya mengenai pembelajaran menggunakan model inkuiri terbimbing terhadap keterampilan proses sains siswa. Kegiatan yang dilakukan pada tahap ini adalah menganalisis data yang diperoleh pada tahap observasi. Berdasarkan hasil analisis data dilakukan refleksi guna melihat kekurangan dan kelebihan yang terjadi saat pembelajaran diterapkan. Kekurangan dan kelebihan dijadikan acuan untuk merencanakan siklus berikutnya.

\section{Hasil Penelitian dan Pembahasan Deskripsi Siklus I}

Siklus I dilaksanakan 3 kali pertemuan pada kelas IV Tema 8 Daerah Tempat Tinggalku dengan KD muatan IPA 3.4 Menghubungkan gaya dengan gerak pada peristiwa di lingkungan sekitar. Berikut persentase hasil aktivitas siswa menggunakan model inkuiri terbimbing siklus I:

Tabel 1. Persentase Hasil Aktivitas Siswa Siklus I

\begin{tabular}{lccc}
\hline \multicolumn{1}{c}{ Aktivitas } & Pertemuan 1 & Pertemuan 2 & Pertemuan 3 \\
\hline Mengajukan pertanyaan yang berkaitan & $31,58 \%$ & $47,37 \%$ & $57,89 \%$ \\
dengan materi & $73,68 \%$ & $89,47 \%$ & $89,47 \%$ \\
Merumuskan masalah yang ditemukan & $21,05 \%$ & $47,37 \%$ & $52,63 \%$ \\
Merumuskan hipotesis & $78,07 \%$ & $81,58 \%$ & $82,46 \%$ \\
Melakukan eksperimen sederhana & $54,39 \%$ & $54,39 \%$ & $54,39 \%$ \\
Menganalisis data & $26,32 \%$ & $52,63 \%$ & $52,63 \%$ \\
Menarik kesimpulan & $47,52 \%$ & $62,14 \%$ & $64,91 \%$ \\
Rata-Rata & & $58,19 \%$ & \\
Rata-Rata Siklus I & & \\
\hline
\end{tabular}

Berdasarkan tabel di atas, aktivitas siswa pada pembelajaran siklus I menggunakan model inkuiri masih banyak yang kurang dengan rata-rata 58,19\%. Sehingga dari aktivitas siswa tersebut dapat diketahui persentase per jenis keterampilan proses sains sebagai berikut: 
Tabel 2. Persentase Jenis Keterampilan Proses Sains

\begin{tabular}{lccc}
\hline Aktivitas & Pertemuan 1 & Pertemuan 2 & Pertemuan 3 \\
\hline Mengobservasi & $78,95 \%$ & $84,21 \%$ & $84,21 \%$ \\
Mengklasifikasi & $63,16 \%$ & $63,16 \%$ & $68,42 \%$ \\
Memprediksi & $68,42 \%$ & $68,42 \%$ & $78,95 \%$ \\
Mengkomunikasikan & $73,68 \%$ & $73,68 \%$ & $73,68 \%$ \\
Rata-rata & $71,05 \%$ & $72,37 \%$ & $76,32 \%$ \\
\hline
\end{tabular}

Berdasarkan tabel di atas, keterampilan proses sains mengobservasi pada siklus I pertemuan 1, 2 dan 3 sudah dalam kategori baik yaitu 78,95\%; 84,21\%; dan 84,21\%. Keterampilan proses sains mengklasifikasikan termasuk dalam kategori cukup pada siklus I pertemuan 1, 2 dan 3 yaitu 63,16\%; 63,16\%; dan 68,42\%. Keterampilan proses sains memprediksi pada siklus I pertemuan 1 dan 2 masih dalam kategori cukup dengan persentase $68,42 \%$. Namun pada siklus I pertemuan 3 sudah dalam kategori baik yaitu $78,95 \%$. Keterampilan proses sains mengkomunikasikan sudah termasuk kategori baik dengan persentase $73,68 \%$. Sedangkan hasil nilai keterampilan proses sains siklus I dapat dilihat pada tabel berikut:

Tabel 3. Nilai Keterampilan Proses Sains Siklus I

\begin{tabular}{lc}
\hline Rata-Rata & 73,21 \\
Nilai Maksimal & 100 \\
Nilai Minimal & 50 \\
Jumlah Siswa Tuntas & 15 siswa $(78,95 \%)$ \\
Jumlah Siswa Tidak Tuntas & 4 siswa $(21,05 \%)$ \\
\hline
\end{tabular}

Berdasarkan hasil tindakan siklus I nilai rata-rata keterampilan proses sains sudah diatas KKM yaitu 73,21 dan jumlah siswa yang tuntas sudah mencapai 78,95\%. Namun ada siswa dalam siklus 1 dengan yang mendapat nilai minimal yaitu 50 sehingga belum tuntas KKM. Ada beberapa yang perlu diperbaiki dalam siklus I menuju siklus II diantaranya, 1) perbaikan guru untuk lebih membimbing siswa dalam tahapan inkuiri merumuskan hipotesis dengan memberikan pertanyaan pancingan dan menuliskan hipotesis tersebut di papan tulis sehingga siswa tidak lupa; 2) memberikan kesempatan kepada siswa untuk menanggapi presentase milik temannya, 3) pemberian pertanyaan inkuiri pada LKPD lebih diarahkan ke penyelidikan dengan memberikan opsi jawaban dan tabel sehingga bisa mengembangan keterampilan mengklasifikasikan dan memprediksi siswa.

Deskripsi Siklus II

Sudah melakukan model inkuiri terbimbing sesuai dengan sintaksnya, hasil aktivitas siswa dapat dilihat pada tabel berikut:

Tabel 4. Persentase Hasil Aktivitas Siswa Siklus II

\section{Aktivitas}

Mengajukan pertanyaan yang berkaitan

dengan materi

Merumuskan masalah yang ditemukan

Merumuskan hipotesis

Melakukan eksperimen sederhana

Menganalisis data

Menarik kesimpulan

Rata-Rata

Rata-Rata Siklus II

\section{Pertemuan 1 Pertemuan 2 Pertemuan 3}

$\begin{array}{lll}63,16 \% & 78,95 \% & 73,68 \% \\ 89,47 \% & 89,47 \% & 89,47 \% \\ 63,16 \% & 89,47 \% & 89,47 \% \\ 85,94 \% & 92,98 \% & 93,86 \% \\ 57,89 \% & 71,93 \% & 77,19 \% \\ 57,89 \% & 73,68 \% & 73,68 \% \\ 69,59 \% & 82,75 \% & 82,89 \% \\ & 78,41 \% & \\ \end{array}$


Berdasarkan data tersebut, rata-rata sktivitas siswa pada siklus II mulai membaik dengan ratarata persentase sebesar $78,41 \%$. Sehingga terdapat kenaikan per keterampilan proses sains siswa seperti pada tabel berikut:

Tabel 5. Persentase Jenis Keterampilan Proses Sains

\begin{tabular}{lccc}
\hline Aktivitas & Pertemuan 1 & Pertemuan 2 & Pertemuan 3 \\
\hline Mengobservasi & $89,47 \%$ & $89,47 \%$ & $89,47 \%$ \\
Mengklasifikasi & $73,68 \%$ & $78,95 \%$ & $78,95 \%$ \\
Memprediksi & $78,95 \%$ & $78,95 \%$ & $84,21 \%$ \\
Mengkomunikasikan & $78,95 \%$ & $84,21 \%$ & $84,21 \%$ \\
Rata-rata & $80,26 \%$ & $82,89 \%$ & $84,21 \%$ \\
\hline
\end{tabular}

Berdasarkan tabel di atas, keterampilan proses sains mengobservasi pada siklus II pertemuan 1, 2 dan 3 sudah dalam kategori sangat baik yaitu 89,47\%. Keterampilan proses sains mengklasifikasikan pada pertemuan 1, 2 dan 3 termasuk dalam kategori baik yaitu 73,68\%; 78,95\% dan 78,95\%. Pada keterampilan memprediksi pertemuan 1, 2, dan 3 sudah termasuk kategori baik yaitu 78,95\%; 78,95\% dam 84,21\%. Keterampilan proses sains mengkomunikasikan sudah termasuk kategori baik pada pertemuan 1, 2 dan 3 yaitu 78,95\%, $84,21 \%$ dan $84,21 \%$. Sedangkan hasil nilai keterampilan proses sains siklus II dapat dilihat pada tabel berikut:

\section{Tabel 6. Nilai Keterampilan Proses Sains Siklus II}

\begin{tabular}{lc}
\hline Rata-Rata & 82,47 \\
Nilai Maksimal & 100 \\
Nilai Minimal & 75 \\
Jumlah Siswa Tuntas & 19 siswa $(100 \%)$ \\
Jumlah Siswa Tidak Tuntas & 0 siswa $(0 \%)$ \\
\hline
\end{tabular}

Pada siklus I kendala dalam melakukan model inkuiri adalah guru belum membimbing siswa dalam hipotesis terbukti dengan aktivitas siswa pada pertemuan 1 hanya mendapat persentase $21,05 \%$; pertemuan ke 2 yang mulai meningkat namun masih kurang yaitu $47,37 \%$ dan pertemuan 3 yaitu 52,63\%. Meskipun adanya peningkatan namun masih dalam kategori kurang. Perbaikan di siklus II yaitu guru membimbing siswa mengajukan hipotesis dengan memberikan pertanyaan pemancing dan menuliskannya di papan tulis. Hal tersebut sejalan dengan Hamruni (2012) salah satu cara yang dapat dilakukan guru adalah dengan mengajukan berbagai berbagai pertanyaan yang dapat mendorong siswa untuk dapat merumuskan jawaban sementara, atau dapat merumuskan berbagai perkiraan kemungkinan jawabaan dari suatu masalah yang dikaji.

Pertanyaan penyelidikan itu berlaku juga dalam analisis pertanyaan percobaan pada LKPD. LKPD yang baik berisi pertanyaan pertanyaan dan berbentuk kolom kolom untuk memudahkan siswa dalam penyelidikan. Namun pada siklus I belum terlalu baik dalam penyusuna LKPD baik pertanyaan maupun kolom-kolom. Hal tersebut sangat berguna dalam mengembangkan keterampilan siswa dalam mengklasifikasikan dan memprediksi. Sehingga pada siklus II diperbaiki.

Pada siklus I guru belum memberikan kesempatan kepada siswa untuk menanggapi presentasi milik teman sehingga berpengaruh pada keterampilan proses mengkomunikasikan. Merumuskan argumen yang masuk akal dan logis untuk membenarkan penjelasan dan kesimpulan (Martin, 2009). Sehingga pada siklus II diperbaiki dengan memberikan kesempatan siswa untuk menanggapi teman yang presentasi. Berikut tabel hasil peningkatan keterampilan proses sains dengan model inkuiri terbimbing: 
Tabel 7. Peningkatan Keterampilan Proses Sains

\begin{tabular}{lcccccc}
\hline Aktivitas & $\begin{array}{c}\text { Pra } \\
\text { Tindakan }\end{array}$ & Siklus I & Peningkatan & Siklus I & Siklus II & $\begin{array}{c}\text { Pening } \\
\text { katan }\end{array}$ \\
\hline Mengobservasi & $63,16 \%$ & $82,46 \%$ & $19,30 \%$ & $82,46 \%$ & $89,47 \%$ & $7,01 \%$ \\
Mengklasifikasi & $42,11 \%$ & $64,91 \%$ & $22,80 \%$ & $64,91 \%$ & $77,19 \%$ & $12,28 \%$ \\
Memprediksi & $52,63 \%$ & $71,93 \%$ & $19,30 \%$ & $71,93 \%$ & $80,70 \%$ & $8,77 \%$ \\
Mengkomunikasikan & $57,89 \%$ & $73,68 \%$ & $15,79 \%$ & $73,68 \%$ & $82,46 \%$ & $8,78 \%$ \\
Rata-rata & $53,95 \%$ & $73,25 \%$ & $19,30 \%$ & $73,25 \%$ & $82,45 \%$ & $9,20 \%$ \\
\hline
\end{tabular}

Adanya peningkatan persentase rata-rata nilai dari pra tindakan ke siklus I yaitu sebanyak 19,30\%. Sedangkan dari siklus I ke siklus II mengalami peningkatan 9,20\% setelah melakukan perbaikan tindakan. Keberhasilan pada siklus II yaitu 100\% siswa tuntas dikarenakan dalam langkah tindakan guru dilakukan sesuai tahapan. Dari pembahasan di atas dapat disimpulkan bahwa penerapan model inkuiri terbimbing dapat meningkatkan keterampilan proses siswa kelas IV SD Negeri 1 Pingit tahun ajaran 2020/2021.

\section{Kesimpulan}

Berdasarkan hasil penelitian ini, maka dapat disimpulkan bahwa penerapan model inkuiri terbimbing dapat meningkatkan keterampilan proses sains siswa. Hal tersebut ditunjukkan dengan pencapaian keterampilan proses sains siswa pada muatan IPA saat pra tindakan termasuk kategori kurang yaitu hanya mencapai rata-rata 52,63 dan hanya ada 8 siswa $(42,11 \%)$ yang mendapat nilai di atas KKM. Setelah diberikan tindakan pada siklus I yaitu dengan menerapkan model inkuiri terbimbing dalam muatan IPA, keterampilan proses siswa meningkat dengan rata-rata 73,21 (kategori baik) dan terdapat 15 siswa $(78,95 \%)$ yang mendapatkan nilai di atas KKM. Pada siklus II pencapaian keterampilan proses meningkat mencapai rata-rata 82,47 (kategori baik) dan ada 19 siswa (100\%) yang mendapatkan nilai di atas KKM setelah dilakukan perbaikan pada tahap merumuskan hipotesis, menganalisis data dan mengkomunikasikan kesimpulan dalam melaksanakan inkuiri terbimbing. Perolehan tersebut sudah memenuhi kriteria keberhasilan dalam penelitian ini.

\section{Saran}

Berdasarkan hasil penelitian ini dapat disampaikan saran kepada guru untuk segera melakukan refleksi sehingga dapat memecahkan persoalan di dalam proses pembelajaran. Salah satunya adalah memperbaiki keterampilan proses sains siswa yang hubungannya dengan hasil belajar. Ketika keterampilan prosesnya baik maka konsep yang didapatkan siswa juga baik. Hal tersebut dapat dikembangkan dengan penerapan model inkuiri terbimbing oleh guru.

\section{Daftar Pustaka}

Ambarsari, W. (2013). Penerapan Pembelajaran Inkuiri Terbimbing Terhadap Keterampilan Proses Sains Dasar Pada Pelajaran Biologi Siswa Kelas Viii Smp Negeri 7 Surakarta. Pendidikan Biologi FKIP UNS. Pendidikan Biologi Volume 5, Nomor 1 Januari 2013 Halaman 81-95.

Anam, K. (2015). Pembelajaran Berbasis Inkuiri Metode dan Aplikasi. Yogyakarta: Pustaka Pelajar.

Ardhiantari, W. (2015). Pengembangan LKS Berbasis Keterampilan Proses Sains pada Materi Hukum-Hukum Dasar Kimia. FKIP Universitas Lampung. Jurnal Pendidikan dan Pembelajaran Kimia, Vol. 4, No.1 Edisi April 2015, 312-323. 
Arikunto dkk. (2008). Penelitian Tindakan Kelas. Jakarta: Bumi Aksara.

Avraamidou, L. (2016). A well-started beginning elementary teacher's beliefs and practices in relation to reform recommendations about inquiry-based science. Cult Stud of Sci Educ (2017) 12:331-353 DOI 10.1007/s11422-015-9700-x. Original Paper. Received: 27 September 2013/Accepted: 17 August 2015/Published online: 29 March 2016 Springer Science+Business Media Dordrecht 2016. University of Nicosia, Nicosia, Cyprus.

Dimyati \& Mudjiono. (2009). Belajar dan Pembelajaran. Jakarta: Rineka Cipta.

Hamruni. (2012). Strategi Pembelajaran. Yogyakarta: Insan Madani.

Juhji. (2016). Peningkatan Keterampilan Proses Sains Siswa Melalui Pendekatan Inkuiri Terbimbing. Iain Sultan Maulana Hasanuddin, Serang. Jurnal Penelitian dan Pembelajaran IPA. JPPI, Vol. 2, No. 1, Juni 2016, Hal. 58-70. E-ISSN 2477-2038 58 .

Kemmis, S., \& McTaggart, R. (2014). The Action Research Planner. Geelong: Deakin University Press.

Martin, D.J. (2009). Elementary Science Methods: A Constructivist Approach. USA: Wadsworth Cengage Learning.

Permendiknas. (2006). Peraturan Menteri Pendidikan Nasional Nomor 22 Tahun 2006 tentang Standar Kompetensi Lulusan.

Prasasti, P.A.T. (2017). Efektivitas Scientific Approach With Guided Experiment pada Pembelajaran IPA untuk Memberdayakan Keterampilan Proses Sains Siswa Sekolah Dasar. Universitas PGRI Madiun. ISSN 2406-8012. Profesi Pendidikan Dasar Vol. 4, No. 1, Juli 2017 : 16-22.

Ramadhanti, A., \& Agustini, R. (2021). Analisis Keterampilan Berpikir Kritis Peserta Didik Melalui Model Inkuiri Terbimbing Pada Materi Laju Reaksi. Jurnal Kependidikan: Jurnal Hasil Penelitian dan Kajian Kepustakaan di Bidang Pendidikan, Pengajaran dan Pembelajaran, 7(2), 385-394. doi:https://doi.org/10.33394/jk.v7i2.3458

Renner, J. W. \& Ragan, W. B. (1968). Teaching Science in the Elementary School. New York: Incorporated.

Samatowa, U. (2011). Pembelajaran IPA di Sekolah Dasar. Jakarta: Indeks.

Sanjaya, W. (2006). Strategi Pembelajaran Berorientasi Standar Proses Pendidikan. Jakarta: Kencana.

Seprianingsih, D. (2017). Pengembangan Perangkat Pembelajaran Biologi Berbasis Inkuiri Terbimbing dalam Meningkatkan Penguasaan Konsep Biologi Siswa. Jurnal Kependidikan: Jurnal Hasil Penelitian dan Kajian Kepustakaan di Bidang Pendidikan, Pengajaran dan Pembelajaran, 3(1). doi:https://doi.org/10.33394/jk.v3i1.467

Suharsimi Arikunto, dkk. (2006). Penelitian Tindakan Kelas. Jakarta: Bumi Aksara.

Sugiyono. (2016). Metode Penelitian Kuantitatif, Kualitatif, dan R\&D. Bandung: Alfabeta.

Trowbridge, L.W. (1990). Becoming a Secondary School Science Teacher. Ohio: Merrill Publishing Company.

Wisudawati, A.W. \& Sulistyowati, E. (2015). Metodologi Pembelajaran IPA. Jakarta: Bumi Aksara. 